Revista de la red interuniversitaria de estudios sobre las literaturas rioplatenses contemporáneas en Francia

$11 \mid 2014$

De niños e infancias

\title{
La casa y el violín
}

Hernán Ronsino

\section{OpenEdition \\ Journals}

Edición electrónica

URL: http://journals.openedition.org/lirico/1829

DOI: $10.4000 /$ lirico.1829

ISSN: 2262-8339

Editor

Réseau interuniversitaire d'étude des littératures contemporaines du Río de la Plata

Referencia electrónica

Hernán Ronsino, «La casa y el violín », Cuadernos LIRICO [En línea], 11 | 2014, Puesto en línea el 01

diciembre 2014, consultado el 04 mayo 2019. URL : http://journals.openedition.org/lirico/1829 ; DOI : 10.4000/lirico.1829

Este documento fue generado automáticamente el 4 mayo 2019.

\section{(c) $(\mathbb{0} \Theta \Theta$}

Cuadernos LIRICO está distribuido bajo una Licencia Creative Commons Atribución-NoComercialSinDerivar 4.0 Internacional. 


\title{
La casa y el violín
}

\author{
Hernán Ronsino
}

\section{NOTA DEL EDITOR}

Hernán Ronsino (Chivilcoy, 1976) enseña sociología en la Universidad de Buenos Aires y en la Facultad Latinoamericana de Ciencias Sociales (FLACSO). Es fundador de la revista En ciernes. Ha publicado las novelas Te vomitaré de mi boca (Libris, 2003), La descomposición (Interzona, 2007), Glaxo (Eterna Cadencia, 2009) y Lumbre (Eterna cadencia, 2013).

\section{La escritura imposible}

1 Nunca pude escribir un poema. Escribir un poema siempre me resultó algo tan imposible como tocar un instrumento musical, como tocar, por el ejemplo, el violín. Cada vez que me puse a rondar la escritura de un poema lo primero que salía era un encabalgamiento de palabras más bien escolares, rimadas. Todos los intentos terminaban desflecados, en una imposibilidad que daba por resultado el abandono. La idea de un poema abandonado en las páginas de un cuaderno cualquiera. Esa figura del abandono siempre la asocié a la figura de un edificio invadido de yuyos. Un yuyal tomando el cuerpo de un poema. En la imposibilidad de escribir, como en una casa abandonada, habita un enigma. De chico viajaba de un modo recurrente a la ciudad de La Plata por un problema de salud que tenía y que nadie en mi ciudad podía atender. Había un médico en La Plata, un tal Fogelberg, que curaba todo tipo de alergias. Alguien, la ex novia o un pariente de la ex novia de un tío mío que se había atendido con Fogelberg, le pasó el dato a mi madre y le dijo que era buenísimo. Que su método curaba. Empezamos a viajar una vez al mes. Viajábamos en micro y para llegar a La Plata a horario, teníamos que tomar el Automotores La Plata que pasaba por mi ciudad a las 5 y media de la mañana. Por eso, un poco después de Mercedes, veíamos contra la ventanilla de qué modo el sol comenzaba a despuntar - según decía mi madre - atrás de Buenos Aires. Para allá, decía, está Buenos Aires. Entonces, cuando pasábamos por Jáuregui, unos kilómetros antes de Luján, ya podíamos ver esa casita 
iluminada, a un lado de la ruta y, por esa época, en construcción. Se trataba de un chalet, de esos típicos de la década del ochenta. Lo curioso era el lugar en donde se lo estaba construyendo. Porque no estaba levantado frente a la plaza del pueblo. El chalecito estaba montado en medio del campo, junto a la ruta. En esos años de viaje a La Plata el chalecito en construcción fue convirtiéndose en un mojón del camino. Después del chalecito comenzaba la invasión urbana. Las extensiones de la metrópolis que, como un pulpo, iba invadiendo la pampa. El chalecito marcaba, más o menos, la mitad del viaje. En ese tiempo habían levantado las paredes y el techo con caída hacia el frente. A la hora que pasábamos con mi madre no había obreros, pero sí se veían las herramientas desplegadas: la máquina que preparaba el cemento, una carretilla, las palas. Cuando el tratamiento por mi alergia terminó, los viajes a La Plata o a Buenos Aires se volvieron cada vez más espaciados. Incluso, muchas veces, podían pasar años sin que tomáramos esa ruta. Creo que el siguiente viaje lo hicimos en auto. Íbamos a un velorio a Pacheco. Un tío de mi madre, un tío italiano de esos que irrumpían cada tanto en las mañanas de domingo, a los gritos y despertando a todo el mundo, un tío que se llamaba Quequeche había muerto. Alguien llamó por teléfono para avisar y el viaje se improvisó. Y salimos todos a la ruta en un auto que no estaba revisado, como le hubiera gustado a mi padre. Un Falcón del año 64. En ese viaje me dormí pero antes de pasar por Jáuregui abrí los ojos. Y me quedé recostado contra la falda de mi madre mirando la cuerina del techo : tenía una infinidad de estrellas incrustadas o caladas. Nunca pude descifrarlo. Estaba en eso cuando mi madre dijo : "Pero esa casa no la terminan nunca". Y entonces yo entendí y me levanté y busqué el chalecito que se perdía, se me iba de los ojos, incompleto. A partir de allí - habrá sido por el modo en que mi madre lo dijo - un misterio comenzó a rondar esa casa. Ese misterio fue acentuándose en el tiempo con la permanencia del abandono: con la invasión de pastizales, con el color que fueron tomando las paredes, esas manchas de musgo, esa oscuridad - que todavía hoy se ve junto a la ruta - pintada como un cuadro negro y recargado.

\section{La posibilidad de un poema}

2 Entonces traté de escribir un poema después de leer, por ejemplo, a Alberto Szpunberg, después de leer este verso en "Cap de Creus". Dice Szpunberg: "También las palabras necesitan de una promesa para arremolinarse en un punto, en un poema, como la espuma en el hueco de la roca". Eso dice Szpunberg. Y yo pienso en aquella casa como una roca que atrapa igual que un astro. Como un astro en medio de la pampa infinita. Escribir un poema me lanza a un vacío semejante al que siento cuando tengo en mis manos un instrumento musical, un violín, por ejemplo. Un verano, tendría siete años, murió el vecino de la casa contigua a la de mis padres. Su hijo después del entierro empezó a vaciar la casa. Empezó a tirar cosas. Mi padre sabía que el hombre que había muerto tenía un violín - había tocado durante una época, en su juventud, en una orquesta de tangos -. El violín estaba descuidado, encintado. No servía. Pero el hijo no dudó y se lo entregó a mi padre. Ese violín pasó a ser uno de mis juguetes preferidos. Por eso, después de unas semanas, les dije a mis padres que quería aprender a tocar. Recién en las vacaciones de invierno mi padre me subió al Falcón 64 y salimos para el conservatorio que estaba en el centro, frente a la plaza. Por eso mi padre se puso esos zapatos que usaba para alguna comunión o para un casamiento. Lloviznaba. Entramos con respeto. Como se entra a la casa de un médico. El conservatorio para mí era un lugar imposible de imaginar, tal vez 
por esa palabra, conservatorio, creo que a mi padre le pasaba algo parecido. Pero cuando entramos fue como si hubiéramos entrado a una escuela. Nos atendió una secretaria. Mi padre le contó el motivo por el cual estábamos ahí. La secretaria nos miró y dijo que esperáramos un minuto. Después nos hizo pasar a la sala del director. El director lo saludó a mi padre - lo conocía de vista, eso fue lo que dijo - y nos hizo sentar. Mi padre volvió a contar el motivo. Yo miraba las fotos del director sobre el escritorio : con familiares, con ex alumnos, el director tocando el trombón. Y en la pared de atrás un cuadro de Alberto Williams junto al cuadro de San Martín. Entonces, después de escuchar a mi padre, el director nos dijo que lo que nosotros queríamos no iba a ser posible. Lamentablemente, dijo. Cuando mi padre escuchó eso, levantó la voz. Pero cómo, lanzó. Yo me estremecí. El director nos calmó y dijo, aclarando, que no iba a ser posible porque desde hacía un año el conservatorio no tenía profesor de violín. No nos mandan, dijo. Y que si yo quería estudiar violín iba a tener que viajar más de cien kilómetros hasta Pergamino. Pero si quiere, propuso, el muchacho se puede anotar en piano o en guitarra. El director le hablaba a mi padre. Entonces mi padre me miró. Pero yo sentí por primera vez algo que no podía explicar muy bien. Elegir violín no era lo mismo que piano o guitarra. Además, yo tenía un violín. El director y mi padre quedaron en que me tomara un tiempo para pensarlo. Pero el tiempo se fue dilatando. Y yo nunca tomé la decisión. Por eso mis padres habrán pensado que ese capricho de aprender violín se me había pasado. Por eso tampoco nunca aprendí música. Cada vez que me aproximo a la escritura de un poema siento la misma imposibilidad que siento cuando tengo en mis manos un violín, por ejemplo. Cada vez que intento rondar la escritura de un poema se me aparece la figura de una casa abandonada en medio del campo. Y el misterio ése, que la sostiene en su abandono. Pero sabemos, es cierto, que la palabra misterio ya no explica nada como dice Zelarayán ("el poeta que escribe porque no puede escribir", así lo nombra Osvaldo Aguirre) en ese bellísimo verso de La gran salina : "La palabra misterio hay que aplastarla como se aplasta una pulga, entre los dos pulgares. La palabra misterio ya no explica nada. / (El misterio es nada y la nada no se explica por sí misma)/ Habría que reemplazar la palabra misterio/ por lo que yo siento cuando pienso en los/ trenes de carga/ que pasan de noche por La gran salina". 